MIRACLE JOURNAL

https://ojs.unhaj.ac.id/index.php/mj
MIRACLE JOURNAL

e-ISSN $2774-4663$

Vol 1, No 2, Juli 2021

Hal 46 - 52

\title{
KETERKAITAN DUKUNGANKELUARGA TERHADAP TINGKAT KECEMASAN IBU HAMIL PRIMIGRAVIDA DALAM MENGHADAPI PERSALINAN DI WILAYAH KERJA PUSKESMAS MOTOBOI KECIL
}

\author{
Agustin $^{1}$, Sitti Nurul Hikma Saleh², Muzayyana ${ }^{3}$, Hairil Akbar ${ }^{*}$ \\ 1,2,3Program Studi DIII KebidananInstitut Kesehatan dan TeknologiGrahaMedika, \\ Kotamobagu, Indonesia \\ ${ }^{4}$ Program Studi Kesehatan Masyarakat Institut Kesehatan dan TeknologiGrahaMedika, \\ Kotamobagu, Indonesia \\ Email: agustinbidan08@gmail.com,nurulhikmasaleh93@gmail.com, muzayyanananna@gmail.com \\ *Corresponding Author: hairil.akbarepid@gmail.com
}

\begin{abstract}
Abstrak
Kehamilan pada umumnya memberikan arti emosional yang sangat besar pada setiap wanita dan akan membuat ibu merasakan kecemasan yang berdampak pada kehamilan ibu dan janin. Kecemasan selama kehamilan dalam proes persalinan yang tidak dapat diatasi ibu dapat menimbulkan ketegangan, menghalangi relaksasi tubuh, menyebabkan keletihan atau bahkan mempengaruhi kondisi janin dalam kandungan, tetapi dengan kehadiran keluarga saat persalinan dapat membuat ibu lebih tenang. Tujuan penelitian menganalisis keterkaitan dukungan keluarga terhadap tingkat kecemasan ibu hamil primigravida dalam menghadapi persalinan di wilayah kerja Puskesmas Motoboi Kecil. Jenis penelitian ini adalah kuantitatif yang bersifat survey analitik dengan menggunakan pendekatan Cross Sectional. Penelitian dilakukan di Puskesmas Motoboi Kecil. Populasi sebanyak 69 orang ibu hamil, sampel sebanyak 30 orang. Teknik pengambilan sampel menggunakan simple random sampling. Analisis data menggunakan uji chi-square. Hasil penelitian menunjukkan terdapat hubungan dukungan keluarga dengan kecemasan ibu hamil primigravida menghadapi persalinan di Puskesmas Motoboi Kecil ( $p$-value $=0,001)$. Diharapkan dapat memberikan penyuluhan tentang kesehatan jiwa yang bermanfaat terhadap psikologis ibu hamil untuk mengurangi kecemasan terutama pada ibu hamil primigravida menghadapi persalinan.
\end{abstract}

Kata kunci: Kecamasan ibu hamil, Dukungan keluarga

\begin{abstract}
Pregnancy in general gives a very big emotional meaning to every woman and will make the mother feel anxiety which has an impact on the pregnancy of the mother and fetus. Anxiety during pregnancy during labor that cannot be overcome by the mother can cause tension, hinder body relaxation, cause fatigue or even affect the condition of the fetus in the womb, but the presence of the family during delivery can make the mother calmer.The purpose of the study was to analyze the relationship between family support and anxiety levels of primigravida pregnant women in facing childbirth in the working area of the Motoboi Kecil Health Center.This type of research is quantitative with an analytical survey using a Cross Sectional approach. The research was conducted at the Motoboi Kecil Health Center. The population is 69 pregnant women, the sample is 30 people. The sampling technique used was simple random sampling. Data analysis using chi-square test.The results showed that there was a relationship between family support and the anxiety of primigravida pregnant women facing childbirth at the Motoboi Kecil Health Center ( $p$-value $=0.001)$.It is hoped that it can provide counseling about mental health that is useful for psychologically pregnant women to reduce anxiety, especially for primigravida pregnant women facing childbirth.
\end{abstract}

Keywords: Anxiety for pregnant women, Family support 


\section{MIRACLE JOURNAL}

https://ojs.unhaj.ac.id/index.php/mj
MIRACLE JOURNAL

e-ISSN $2774-4663$

Vol 1, No 2, Juli 2021

Hal 46 - 52

\section{Pendahuluan}

Pelayanan kesehatan maternal dan neonatal merupakan salah satu unsur penentu status kesehatan(Asmiati \& Hairil, 2021). Kehamilan merupakan suatu peristiwa alami dan fisiologis yang terjadi pada wanita yang di dahului oleh suatu zigot dan akhirnya menjadi janin yang mengalami proses perkembangan dan pertumbuhan sampai proses persalinan. Kehamilan ini dimulai dari hasil pembuahan sel telur dan sel sperma sehingga terjadi pertumbuhan dan perkembangan janin sampai dengan proses persalinan. Persalinan adalah saat yang dinantikan oleh setiap pasangan yang sudah menikah dan sangat mengharapkan kehadiran seorang anak(Manuaba, 2012).

Menurut (Sari, 2017)kehamilan pada umumnya memberikan arti emosional yang sangat besar pada setiap wanita karena kehamilan merupakan salah satu ekspresi perwujudan identitas sebagai calon ibu.Selama kehamilan seringkali muncul perasaan cemas yang berlebihan pada ibu yang sedang hamil terutama pada ibu primigravida yang baru pertama kali melahirkan anak pertama. Kecemasan pada ibu diakibatkan karena ketidak mampuan ibu dalam mengontrol kecemasan dan psikologis sehingga munculah perasaan tegang, panic, takut, stress dan khawatir dalam menghadapi persalinan apalagi si cabang bayi yang di harapkan lahir dengan keadaan tidak normal atau cacat, oleh karena itu tingkat kecemasan ibu akan semakin akut.

Menurut(Na'im, 2010) kehamilan dan persalinan adalah suatu krisis maturitas yang dapat menimbulkan kecemasan atau bahkan stres, tetapi berharga karena wanita tersebut menyiapkan diri untuk memberi perawatan dan mengemban tanggung jawab yang lebih besar. Seiring persiapan menghadapi peran baru, wanita mengubah konsep dirinya agar siap menjadi orang tua. Pertumbuhan ini membutuhkan penguasaan tugas-tugas tertentu, menerima kehamilan, mengidentifikasi peran ibu, mengatur hubungan dengan pasangannya, membangun hubungan dengan anak yang belum lahir, dan mempersiapkan diri menghadapi persalinan.

Menurut data World Health Organization (WHO) kematian ibu masih cukup tinggi, setiap hari diseluruh dunia sekitar 800 perempuan meninggal akibat komplikasi dalam kehamilan atau persalinan. Pada tahun 2013, terdapat 289.000 perempuan meninggal selama dan setelah masa kehamilan serta persalinan. Angka kematian ibu di dunia pada tahun 2013 yaitu jumlah kematian ibu per 100.000 kelahiran hidup) menurun hanya $2,6 \%$ per tahun. $80 \%$ kematian maternal merupakan akibat meningkatnya komplikasi selama kehamilan, persalinan dan setelah persalinan. Sekitar 99\% dari seluruh kematian ibu terjadi di negara berkembang penyebab langsung kematian ibu hampir 90\% terjadi pada saat persalinan dan segera setelah persalinan(Depkes RI, 2014).

Kecemasan menunjukkan reaksi terhadap bahaya yang memperingatkan orang dari dalam secara naluri, bahwa ada bahaya dan orang yang bersangkutan mungkin kehilangan kendali dalam situasi tersebut. Kehamilan dapat merupakan sumber stressor kecemasan, terutama pada seorang ibu yang baru mengalaminya. Kecemasan pada ibu hamil apabila tidak ditangani dengan serius akan membawa dampak dan pengaruh terhadap fisik dan psikis, baik pada ibu maupun janin(Rosita, 2014).

Adapun kecemasan menjelang persalinan ibu hamil akan muncul pernyataan dan bayangan apakah dapat melahirkan normal, cara mengejan, apakah akan terjadi sesuatu saat melahirkan, atau apakah bayi lahir selamat, akan semakin muncul dalam benak ibu, kondisi ini dapat menyebabkan kecemasan dan ketegangan lebih lanjut sehingga membentuk suatu siklus umpan balik yang dapat meningkatkan intensitas emosional secara keseluruhan(Saleh, 2021). 


\section{MIRACLE JOURNAL}

https://ojs.unhaj.ac.id/index.php/mj
MIRACLE JOURNAL

e-ISSN $2774-4663$

Vol 1, No 2, Juli 2021

Hal 46 - 52

Menurut Friedman, 1998dukungan keluarga merupakan suatu strategi intervensi preventif yang paling baik dalam membantu anggota keluarga yang mengalami masalah yang berdampak pada kecemasan yang bertujuan untuk meningkatkan dukungan keluarga yang adekuat, sehingga peran serta keluarga sangat diharapkan untuk mengurangi kecemasan selama kehamilan dan pada saat menghadapi persalinannya.

Berdasarkan studi pendahuluanawal yang di lakukan di Puskesmas Motoboi Kecil, dengan melakukan wawancara kepada kepala ruangan terdapat ibu hamil Primigravida dengan jumlah Total 69ibu hamil primigravida 3 bulan terakhir dari bulan november 2019, sampai januari 2020. Dari hasil wawancara kepada 10 orang ibu hamil, 5 orang ibu hamil mengatakan cemas menghadapi persalinan, kecemasan di akibatkan karena semakin dekat dengan waktu persalinan, faktor yang mempengaruhi kecemasan ibu tersebut diantaranya adalah umur, pendidikan, keuangan atau sosial ekonomi dan status gizi dari ibu tersebut. Terdapat 3 orang ibu hamil yang tidak mengalami kecemasan menghadapi persalinan yang semakin dekat dan 2 orang ibu hamil mengatakan tidak ada dampingan dari keluarga untuk memeriksa kesehatan. Rata-rata ibu hamil memeriksa kandungan di puskesmas datang sendiri tanpa dampingan dari orang tua atau pasangan.Berdasarkan uraian di atas tujuan penelitian menganalisis keterkaitan dukungan keluarga terhadap tingkat kecemasan ibu hamil primigravida dalam menghadapi persalinan di wilayah kerja Puskesmas Motoboi Kecil.

\section{Metode Penelitian}

Jenis penelitian ini adalah kuantitatif yang bersifat survey analitik dengan menggunakan pendekatan Cross Sectional. Penelitian dilakukan di Puskesmas Motoboi Kecil. Populasi sebanyak 69 orang ibu hamil, sampel sebanyak 30 orang. Teknik pengambilan sampel menggunakan simple random sampling. Analisis data menggunakan uji chi-square.

\section{Hasil dan Pembahasan}

\section{Analisis Univariat}

1. Karakteristik Responden Berdasarkan Umur

Tabel. 1 Distribusi Frekuensi Responden berdasarkan Umur Ibu Hamil Primigravida di Wilayah KerjaPuskesmas Motoboi Kecil

\begin{tabular}{lcc}
\hline Umur & Frekuensi & Persentase (\%) \\
\hline 16-20 Tahun & 10 & 33,3 \\
\hline $21-25$ Tahun & 12 & 40,0 \\
\hline 26-30 Tahun & 8 & 26,7 \\
\hline Total & 30 & 100 \\
\hline
\end{tabular}

Berdasarkan Tabel 1 distribusi frekuensi umur responden ibu hamil primigravida menghadapi dalampersalinan di wilayah kerja Puskesmas Motoboi Kecildimana responden yang berumur 1620 tahun sebanyak 10 orang $(33,3 \%)$, berumur $21-25$ tahun sebenyak 12 orang $(40,0 \%)$, berumur 26-30 tahun sebanyak 8 orang $(26,7 \%)$.

2. Karakteristik Respon Berdasarkan Pendidikan 


\section{MIRACLE JOURNAL}

https://ojs.unhaj.ac.id/index.php/mj
MIRACLE JOURNAL

Tabel 2 Distribusi Frekuensi Responden Berdasarkan Pendidikan Ibu Hamil

Primigravida di Wilayah KerjaPuskesmas Motoboi Kecil

\begin{tabular}{lll}
\hline Pendidikan & Frekuensi & Persentase(\%) \\
\hline SMP & 3 & 10,0 \\
\hline SMA & 23 & 76,7 \\
\hline Perguruan Tinggi & 4 & 13,3 \\
\hline Total & 30 & 100
\end{tabular}

Berdasarkan Tabel 2 distribusi frekuensi berdasarkan pendidikan responden ibu hamil primigravida dalammenghadapi persalinan di wilayah kerja Puskesmas Motoboi Kecil, dimanaresponden dari pendidikan SMP sebanyak 3 orang (10,0\%), SMA sebanyak 23 orang $(76,7 \%)$, dan perguruantinggi sebanyak 4 orang $(13,7 \%)$.

3. Karakteristik Responden Berdasarkan Dukungan Keluarga

Tabel 3 Distribusi Frekuensi Responden Berdasarkan Dukungan Keluarga Ibu Hamil Primigravida di Wilayah KerjaPuskesmas Motoboi Kecil

\begin{tabular}{lll}
\hline DukunganKeluarga & Frekuensi & Persentase(\%) \\
\hline Kurang & 16 & 53.3 \\
\hline Baik & 14 & 46,7 \\
\hline Total & 30 & 100 \\
\hline
\end{tabular}

Berdasarkan Tabel3 distribusi frekuensi berdasarkan dukungan keluarga ibu hamil primigravida dalammenghadapi persalinan di wilayah kerja Puskesmas Motoboi Kecil, responden dengan dukungan tidak baik sebanyak 16 orang (53,3\%), sedangkan responden dengan dukungan baik sebanyak 14 orang $(46,7 \%)$.

4. Karakteristik Responden Berdasarkan TingkatKecemasan

Tabel 4 Distribusi Frekuensi Responden Berdasarkan Tingkat Kecemasan Ibu Hamil

Primigravida di Wilayah KerjaPuskesmas Motoboi Kecil

\begin{tabular}{lll}
\hline Tingkat & Frekuensi & Persentase(\%)
\end{tabular}

Kecemasan

\begin{tabular}{lcc}
\hline Ringan & 15 & 50,0 \\
\hline Sedang & 15 & 50,0 \\
\hline Total & 30 & 100
\end{tabular}

Berdasarkan Tabel4 distribusi frekuensi kecemasan ibu hamil primigravida dalammenghadapi persalinan di wilayah kerja Puskesmas Motoboi Kecil, responden dengan tingkat kecemasan sedang sebanyak 15 orang $(50,0 \%)$, dan tingkat kecemasan sedang sebanyak 15 orang $(50,0 \%)$.

\section{AnalisisBivariat}

Tabel 5 Keterkaitan Dukungan Keluarga terhadapTingkat Kecemasan Ibu Hamil 


\section{MIRACLE JOURNAL}

https://ojs.unhaj.ac.id/index.php/mj
MIRACLE JOURNAL

e-ISSN $2774-4663$

Vol 1, No 2, Juli 2021

Hal 46 - 52

Primigravida dalamMenghadapi Persalinan di Wilayah KerjaPuskesmas

Motoboi Kecil

\begin{tabular}{|c|c|c|c|c|c|c|c|}
\hline \multirow{3}{*}{$\begin{array}{l}\text { DukunganKeluarg } \\
\text { a }\end{array}$} & \multicolumn{4}{|c|}{ Tingkat Kecemasan } & \multirow[b]{2}{*}{$\mathrm{N}$} & \multirow[b]{2}{*}{ Total $(\%)$} & \multirow{3}{*}{ p-value } \\
\hline & \multicolumn{2}{|c|}{$\begin{array}{c}\text { KecemasanRinga } \\
\mathrm{n}\end{array}$} & \multicolumn{2}{|c|}{$\begin{array}{l}\text { Kecemasan } \\
\text { Sedang }\end{array}$} & & & \\
\hline & $\mathrm{N}$ & $\%$ & $\mathrm{~N}$ & $\%$ & & & \\
\hline Kurang & 3 & 10,0 & 13 & 40,6 & 16 & 53,3 & \\
\hline Baik & 12 & 40,0 & 2 & 8,3 & 14 & 46,7 & \\
\hline
\end{tabular}

Berdasarkan Tabel 5 menunjukan sebagian besar ibu dengan primigravida memiliki dukungan keluarga kurang dengan kecemasan ringan sebanyak 3 orang $(10,0 \%)$, dan dukungan keluarga kurang dengan kecemasan sedang sebanyak 13 orang (40,6\%). Sedangkan dukungan keluarga baik yang memiliki kecemasan ringan sebanyak 12 orang (20,0\%), dan dukungan keluarga baik dengan kecemasan sedang sebanyak 2 orang $(8,3 \%)$.Berdasarkanhasil uji chi-squaredidapatkan $p$ value $=0,001$ yang menunjukan bahwa nilai tersebut $<0,005$ sehingga dinyatakan terdapat hubungan dukungan keluarga terhadaptingkatkecemasan ibu hamil primigravida dalammenghadapi persalinan di wilayah kerjaPuskesmasMotoboi Kecil.

Dari hasil penelitian ini menunjukan bahwa ibu primigravida dengan dukungan keluarga kurang lebih banyak memiliki tingkatkecemasan sedang.Begitu juga ibu dengan primigravida yang memiliki dukungan keluarga baik lebih banyak memiliki tingkat kecemasanringan. Dalam penelitian ini juga di temukan 3 orang $(10,0 \%)$ responden yang memiliki tingkat kecemasan ringan dengan dukungan keluarga kurang, dan 2 orang responden $(8,3 \%)$ memiliki tingkat kecemasan sedang dengan dukungan keluarga baik.

Dari hasil uji statistikChi-Square penelitian ini menunjukan bahwa ada hubungan dukungan keluarga terhadaptingkatkecemasan ibu hamil primigravida dalammenghadapi persalinan di wilayah kerjaPuskesmas Motoboi Kecildengan nilaip-value $=0,001(<0,05)$. Dukungan keluarga yang baik akan sangat mempengaruhi kecemasan yang baik pada ibu hamil menghadapi persalinan. Adapun faktor yang mempengaruhi kecemasan ibu diantaranya umur yang belum matang dan pengetahuan yangkurang serta dukungan dan motifasi dari keluarga akan sangat mempengaruhi kecemasan ibu dalam persiapan kelahiran, apalagi pada ibu hamil primigravida yang baru pertama kali akan menghadapi persalinan sehingga tanpa dukungan yang baik akan sangat mempengaruhi kecemasan pada ibu menghadapi persalinan.

Kehamilan primigravida merupakan pengalaman pertama kali dalam priode kehidupannya, situasi ini dapat menyebabkan perubahan drastic baik pada fisik ibi maupun psikologis(Pieter, H, 2010).Proses kehamilan sampai dengan persalinan seringkali mengakibatkan aspek-aspek psikologis sehingga menimbulkan berbagai permasalahan psikologis bagi ibu hamil, apalagi bagi ibu dengan persalinan pertama salah satunya adalah kecemasan. Kecemasan merupakan perasaan yang paling umum dialami oleh ibu menjelang persalinan yang mengancam jiwanya, sebagian besar berfokus pada hubungan antara dukungan keluarga dengan kecemasan ibu dalam proses kehamilan sampai dengan kelahiran. 


\section{MIRACLE JOURNAL}

https://ojs.unhaj.ac.id/index.php/mj
MIRACLE JOURNAL

e-ISSN $2774-4663$

Vol 1, No 2, Juli 2021

Hal 46 - 52

Penelitian yang dilakukan di PoliklinikKebidanan RSUP Dr. M. Djamil Padang tentang hubungan karakteristik ibu hamil trimester III dengan tingkat kecemasan dalam menghadapi persalinan menunjukkan bahwa terdapat hubungan karakteristik ibu hamil trimester III dengan tingkat kecemasan dalam menghadapi persalinan (Rahmi, 2009). Menurut penelitian di RB Harapan Bunda Surakartamenyebutkan bahwa menghadapi kehamilan dan persalinan diperlukan dukungan dan peran serta suami (Susilowati, 2012). Adanya dukungan dari orang lain, dapat mengurangi kecemasan bila seseorang sedangan mengalami stress(Aprianawati, R.B., Sulistyorini, 2012). Penelitian lain di Jepang menyebutkan dukungan suami yang diberikan kepada istri selama kehamilan sampai 6 setelah kelahiran dapat meningkatkan kualitas kesehatan ibu dan meningkatkan perawatan anak (Nohara M, 2009).Hasil penelitian yang dilakukan di KabupatenBuolProvinsi Sulawesi Tengah menunjukan nilai $\mathrm{p}$-value $=0,001<0,005$ berarti ada hubungan antara dukungan keluarga dengan tingkat kecemasan ibu hamil(Arifin, 2015).

Dukungan suami menjadi salah satu poin penting dalam suatu keluarga untuk menjamin suatu keluarga yang sehat dan bahagia(Akbar, 2018). Selainitudukungan keluarga merupakan sikap tindakan dan penerimaan keluarga terhadap anggota keluarganya.Dukungan keluarga yang ditujukan akan memberikan efek yang baik dan bermanfaat bagi kesehatan ibu, oleh karena itu dukungan keluarga sangat memiliki adil yang besar dalam menentukan status kesehatan ibu, jika seluruh keluarga mengharapkan kehamilan, mendukung, bahkan memperlihatkan dukungannya dalam berbagai hal maka ibu hamil akan lebih percaya diri, bahagia, dan siap dalam menghadapi persalinan.

\section{Kesimpulan}

Terdapat hubungan dukungan keluarga terhadap tingkat kecemasan ibu hamil primigravida dalam menghadapi persalinan di Puskesmas Motoboi Kecil ( $p$-value=0,001).

\section{Referensi}

Akbar, H. (2018). Faktor Yang Berhubungan Dengan Penggunaan Alat Kontrasepsi Pada Pasangan Usia Subur Di Desa Lohbener Kabupaten Indramayu. Gema Wiralodra, 9(2), 164-182. https://doi.org/10.31943/gemawiralodra.vol9.iss2.350

Aprianawati, R.B., Sulistyorini, I. (2012). Hubungan Antara Dukungan Keluarga Dengan Kecemasan Ibu Hamil Menghadapi Kelahiran Anak Pertama Pada Masa Triwulan Ketiga. Jurnal Psikologis.

Arifin, A. (2015). Ibu Hamil Menghadapi Proses Persalinan Di Puskesmas Budilatama Kecamatan Gandung Kabupaten Buol Provinsi Sulawesi Tengah. EJournal Keperawatan, 3(Volume 3 Nomor 2), 2, 3 .

Asmiati, S. N. H. S., \& Hairil, A. (2021). The Relationship Between Hypertension During Pregnancy And The Incidence Of Neonatory Asphysia In Kotamobagu Regional Hospital. 1, 75-80. https://doi.org/10.47650/pjphsr.v1i1.211 


\section{MIRACLE JOURNAL}

https://ojs.unhaj.ac.id/index.php/mj

Depkes RI. (2014). Angka Kematian Ibu di Dunia. Depkes RI.

Manuaba. (2012). Pengantar Kuliah Obstetri. EGC.

Na'im, N. J. (2010). Hubungan Dukungan Keluarga dengan Tingkat Kecemasan Ibu Primipara Menghadapi Persalinan di Puskesmas Pamulang Kota Tangerang Selatan. Universitas Islam Negeri Syarif Hidayatullah Jakarta.

Nohara M, M. S. (2009). Family support and quality of life of pregnant women during pregnancy and after birth. Japanese Journal of Public Health, 56(12).

Pieter, H, Z. dan N. L. (2010). Pengantar Psikologi untuk Kebidanan. Kencana Prenada Media Group.

Rahmi, L. (2009). Hubungan Usia, Tingkat Pendidikan, Dukungan Suami, dan Dukungan Keluarga Dengan Tingkat Kecemasan Menjelang Persalinan Pada Ibu Primigravida Trimester III di Poliklinik Kebidanan Rsup Dr. M. Djamil Padang Tahun 2009. Universitas Andalas.

Rosita. (2014). Hubungan Dukungan Keluarga dengan Tingkat Kecemasan Ibu Primigravida Menghadapi Persalinan di Puskesmas Wongkaditi Kota Gorontalo. Universitas Negeri Gorontalo.

Saleh, M. S. N. H. S. R. H. A. (2021). Efektivitas Senam Hamil sebagai Pelayanan Prenatal dalam. LOSARI: Jurnal Pengabdian Kepada Masyarakat, 3(1), 1-7.

Sari, F. S. (2017). Dukungan Keluarga Dengan Kecemasan Primigravida Menjelang Persalinan Trisemester III. Jurnal Ipteks Terapan, 11(2), 55. https://doi.org/10.22216/jit.2017.v11i2.1414

Susilowati, D. (2012). Pengaruh Dukungan Keluarga Dan Paritas Terhadap Kecemasan Ibu Hamil Trimester III Dalam Menghadapi Persalinan Di RB Harapan Bunda. Universitas Sebelas Maret. 